\title{
Peningkatan Berat Badan Bayi Baru Lahir dengan Seksio Sesarea yang Diberikan Kombinasi ASI dengan Susu Formula Mengandung Probiotik dan Nonprobiotik
}

\author{
Tetty Yuniati \\ Departemen Ilmu Kesehatan Anak Fakultas Kedokteran Universitas Padjadjaran-RS Dr. Hasan Sadikin, Bandung
}

\begin{abstract}
Latar belakang. Penelitian terdahulu melaporkan pro-kontra bahwa suplementasi probiotik meningkatkan berat badan bayi dibandingkan tanpa probiotik.

Tujuan. Menentukan perbedaan peningkatan berat badan bayi dari saat lahir sampai usia 4 minggu yang diberikan kombinasi ASI dengan susu formula mengandung probiotik dan nonprobiotik.

Metode. Penelitian randomized open label clinical dilakukan selama periode November 2009 sampai Oktober 2010 pada 96 bayi normal, $\mathrm{BBL} \geq 2.500 \mathrm{~g}$ dengan orangtua tidak mempunyai riwayat alergi, lahir dengan seksio sesarea di RS Hasan Sadikin Bandung. Selama 4 minggu 48 bayi diberikan ASI dan susu formula probiotik dan 48 bayi ASI dan nonprobiotik sebagai kontrol dan setiap hari dicatat lama menyusui dan jumlah formula yang diberikan. Analisis statistik dengan Chi-square untuk data kategori dan uji t untuk data numerik serta perbedaan peningkatan berat badan antara kedua kelompok dengan analysis of variance (ANOVA) repeated measure.

Hasil. Karakteristik keluarga tidak berbeda bermakna antara kedua golongan bayi. Jenis kelamin antara kedua kelompok tidak berbeda $(\mathrm{p}>0,05)$. Lama menyusui selama 4 minggu pada golongan probiotik dan nonprobiotik masing-masing $2.789 \pm 1.308,52$ dan 3.055 $\pm 1.515,22$ menit $(\mathrm{p}=0,512)$, sedangkan jumlah susu formula yang diberikan selama 4 minggu $7.029 \pm 2.031,57$ dan $6.583 \pm 1.320,17 \mathrm{~mL}(\mathrm{p}=0,496)$. Berat badan pada saat lahir dan usia 4 minggu pada kelompok probiotik $3.153 \pm 326,89 \mathrm{~g}$ dan $4.150 \pm 413,12 \mathrm{~g}(\mathrm{p}=0,786)$ dan kelompok nonprobiotik $3.113 \pm 395,06 \mathrm{~g}$ dan $4.070 \pm 490,73 \mathrm{~g}(\mathrm{p}=0,382)$, sedangkan perbedaan peningkatan berat badan pada kelompok probiotik $997 \pm 86.23 \mathrm{~g}$ dan kelompok nonprobiotik $957 \pm 95,67 \mathrm{~g}(\mathrm{p}=0,258)$. Hasil uji ANOVA repeated measure menunjukkan jenis susu formula tidak memberikan pengaruh yang bermakna terhadap peningkatan berat badan bayi.

Kesimpulan. Peningkatan berat badan bayi sejak lahir sampai usia 4 minggu yang mendapat kombinasi ASI dan susu formula mengandung probiotik dan tidak mengandung probiotik tidak berbeda. Sari Pediatri 2012;14(4):251-5.
\end{abstract}

Kata kunci: kelahiran seksio sesarea, peningkatan berat badan, probiotik

\begin{abstract}
Alamat korespondensi:
Dr. Tetty Yuniati, Sp.A, Departemen Ilmu Kesehatan Anak Fakultas Kedokteran Universitas Padjadjaran/RS dr. Hasan Sadikin, Jl. Pasteur 38 Bandung 40163. Telp. (022) 2034426, Fax. (022) 2035957. E-mail: Tetty-farhan@mailcity.com
\end{abstract}

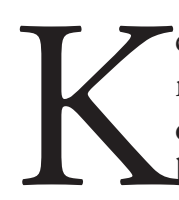
enaikan berat badan dan jenis susu merupakan hal yang sering ditanyakan oleh orangtua bayi baru lahir. Pertumbuhan atau kenaikan berat badan bayi baru lahir selain 
dipengaruhi faktor genetik, juga dipengaruhi oleh jenis minuman yang diberikan. ${ }^{1}$ Borys ${ }^{2}$ melaporkan bahwa bayi baru lahir yang mendapat ASI atau formula, pertumbuhan berat dan tinggi badan bayi laki-laki pada usia 1 bulan lebih tinggi dibandingkan dengan bayi perempuan. ${ }^{2}$ Penelitian yang dilakukan pada bayi sapi sehat yang diberikan probiotik selama 8 minggu, kenaikan berat badannya tidak berbeda dibandingkan dengan bayi sapi yang tidak diberikan probiotik. ${ }^{3,4} \mathrm{Hal}$ yang berbeda dilaporkan pada sapi dan tikus baru lahir yang diberikan probiotik selama 2 bulan tanpa pemberian antibiotik, peningkatan berat badan lebih tinggi dibandingkan dengan tanpa probiotik. ${ }^{5-8}$ Begitu pula pada bayi sapi baru lahir dan bayi manusia prematur yang mendapat antibiotik serta diberikan suplemen probiotik, pertambahan berat badan lebih tinggi dibandingkan dengan tanpa suplemen probiotik. ${ }^{9-13}$

Bayi lahir dengan seksio sesarea pola mikrobiota usus dalam 6 bulan pertama berbeda dengan kelahiran per-vaginam, yaitu pola mikrobiota didominasi oleh Clostridium difficile dan bukan bifidobakterium sehingga akan mempengaruhi respons imun dan mengganggu kesehatan. ${ }^{14-17}$ Bagaimana pengaruh susu formula yang mengandung probiotik terhadap peningkatan berat badan pada bayi baru lahir dengan seksio sesarea sampai usia 4 minggu sampai saat ini belum dilaporkan.

Tujuan penelitian ini untuk mengetahui apakah terdapat perbedaan peningkatan berat badan bayi baru lahir sehat yang diberikan kombinasi ASI dan formula mengandung probiotik dibandingkan dengan bayi yang mendapat kombinasi ASI dengan susu formula nonprobiotik.

\section{Metode}

Subjek adalah bayi yang lahir di Bagian Anak RS dr Hasan Sadikin Bandung periode November 2009-Oktober 2010 dengan kriteria inklusi bayi lahir sehat, cukup bulan, lahir secara seksio sesarea dengan berat badan lahir $\geq 2.500$ g yang orangtuanya tidak mempunyai riwayat alergi dengan menggunakan kuesioner alergi yang dikeluarkan oleh IDAI (2007). Subjek dan ukuran sampel diperoleh dari penelitian yang berjudul "Dampak pemberian B. lactis terhadap mikrobiota feses, marker imun dan SigA feses pada bayi yang lahir dengan seksio sesarea”. Metode yang digunakan adalah randomized open label clinical trial. Subjek secara permutated random dibagi menjadi dua kelompok, yaitu kelompok pertama mendapat kombinasi ASI dan susu formula mengandung probiotik dan kelompok kedua adalah bayi yang mendapat kombinasi ASI dan susu formula tidak mengandung probiotik (nonprobiotik) dari pabrik yang sama dan diberikan sejak lahir sampai usia 4 minggu. Pada saat lahir dan usia 4 minggu dilakukan penimbangan berat badan. Setiap hari dilakukan pencatatan lama menyusui dan jumlah formula yang dihabiskan bayi sampai usia 4 minggu. Selain itu, dicatat usia ibu, lama pendidikan ibu, pendidikan ayah dan ibu, saudara kandung, jenis kelamin bayi, dan setiap minggu dilakukan pemeriksaan fisis serta kejadian penyakit. Data karakteristik subjek penelitian dan faktor yang berhubungan dengan peningkatan berat badan bayi baru lahir, untuk data numerik dilakukan uji t tidak berpasangan dan data kategorik dianalisis dengan Chi-square. Perbedaan peningkatan berat badan saat lahir sampai usia 4 minggu antara bayi yang mendapat kombinasi ASI dan susu formula mengandung probiotik dan nonprobiotik dianalisis dengan analysis of variance (ANOVA) repeated measures. Kemaknaan ditentukan berdasarkan $\mathrm{p}<0,05$ dengan piranti lunak SPSS 17.0.

\section{Hasil}

Selama periode penelitian di RS dr Hasan Sadikin lahir 265 bayi dengan seksio sesarea mempergunakan bius total dan ibu yang meminta pemberian susu formula 108 orang, kemudian dibagi menjadi dua kelompok, yaitu kelompok kombinasi ASI dengan susu formula probiotik dan kelompok ASI dengan susu formula nonprobiotik, masing-masing kelompok 54 orang. Pada follow-up selama 4 minggu 12 orang drop out (1 orang pindah rumah, 11 orang hanya mendapat ASI) sehingga masing-masing kelompok menjadi 48 orang. Karakteristik keluarga subjek penelitian tertera pada Tabel 1.

Tabel 1 menunjukkan bahwa usia rata-rata ibu 29-31 tahun pada kedua kelompok sehingga bukan merupakan kelompok ibu dengan risiko tinggi. Lama pendidikan ibu rata-rata pada kedua kelompok adalah sekolah menengah atas. Sebagian besar ayah pada kedua kelompok tersebut bekerja (94\% dan 96\%), sedangkan ibu sebagian besar tidak bekerja. Pada kedua 
Tabel 1. Karakteristik keluarga subjek penelitian

\begin{tabular}{|c|c|c|c|}
\hline \multirow{2}{*}{ Karakteristik } & Probiotik $(n=48)$ & Nonprobiotik $(\mathrm{n}=48)$ & \multirow{2}{*}{$\mathrm{p}$} \\
\hline & \multicolumn{2}{|c|}{$\mathrm{n}(\%)$ atau rerata $\pm \mathrm{SB}$} & \\
\hline Usia ibu (tahun) & $31 \pm 6,07$ & $29 \pm 5,34$ & $0,039 *$ \\
\hline Lama pendidikan ibu (tahun) & $11 \pm 2,81$ & $11 \pm 2,80$ & $0,379^{*}$ \\
\hline \multicolumn{4}{|l|}{ Pekerjaan ayah $(\%)$} \\
\hline Tidak & $3(6)$ & $2(4)$ & $0,500^{* *}$ \\
\hline Bekerja & $45(94)$ & $46(96)$ & \\
\hline \multicolumn{4}{|l|}{ Pekerjaan ibu (\%) } \\
\hline Tidak & $36(75)$ & $38(79)$ & $0,627^{* *}$ \\
\hline Bekerja & $12(25)$ & $10(21)$ & \\
\hline \multicolumn{4}{|l|}{ Saudara kandung (\%) } \\
\hline Tidak & $15(31)$ & $17(35)$ & $0,665^{*}$ \\
\hline Ya & $33(69)$ & $31(65)$ & \\
\hline
\end{tabular}

Keterangan: * uji t tidak berpasangan ${ }^{* *}$ uji Chi-square

Tabel 2. Faktor yang berhubungan dengan peningkatan berat badan bayi baru lahir

\begin{tabular}{lccc}
\hline \multirow{2}{*}{ Karakteristik } & Probiotik $(\mathrm{n}=48)$ & Nonprobiotik $(\mathrm{n}=48)$ & $\mathrm{p}$ \\
\cline { 2 - 2 } & $\mathrm{n}(\%)$ atau rerata $\pm \mathrm{SB}$ & \\
\hline Jenis kelamin $(\%)$ & $30(62)$ & $24(50)$ & $0,217^{* *}$ \\
$\quad$ Laki-laki & $18(38)$ & $24(50)$ & \\
$\quad$ Perempuan & $2.789 \pm 1.308,52$ & $3.055 \pm 1.515,22$ & $0,512^{*}$ \\
Lama menyusui selama 4 minggu (menit) & $7.029 \pm 2.031,57$ & $6.583 \pm 1.320,17$ & $0,496^{*}$ \\
Jumlah susu formula selama 4 minggu (mL) & &
\end{tabular}

Keterangan: * uji t tidak berpasangan ** uji Chi-square

Tabel 3. Dampak probiotik pada peningkatan berat badan saat lahir sampai usia 4 minggu*

\begin{tabular}{lccc}
\hline Jenis susu & Berat badan lahir $(\mathrm{g})$ & Berat badan usia 4 minggu(g) & Peningkatan berat badan $(\mathrm{g})$ \\
\hline Probiotik & $3.153 \pm 326,89$ & $4.150 \pm 413,12$ & $997 \pm 86,23$ \\
Nonprobiotik & $3.113 \pm 395,06$ & $4.070 \pm 490,73$ & $957 \pm 95,67$ \\
\hline
\end{tabular}

*Analisis ANOVA repeated measure: faktor jenis susu formula $\mathrm{p}=0,446$; faktor waktu $\mathrm{p}=0,000$; interaksi antara waktu dan jenis susu formula $\mathrm{p}=0,525$

kelompok lebih banyak yang mempunyai saudara kandung (69\% dan 65\%).

Tabel 2 memperlihatkan bahwa pada kelompok probiotik laki-laki lebih banyak daripada perempuan, sedangkan kelompok nonprobiotik jumlah lakilaki sama dengan perempuan tetapi antara kedua kelompok tidak berbeda secara bermakna $(\mathrm{p}=0,217)$. Lama menyusui jika dikonversikan pada jumlah ASI (1 menit=6 mL) pada kelompok probiotik adalah
2.789 menit $(16.716 \mathrm{~mL})$, berarti $2,3 \mathrm{x}$ dibandingkan dengan jumlah susu formula $(7.029 \mathrm{~mL})$. Demikian pula pada kelompok nonprobiotik lama menyusui 3.055 menit (jumlah ASI: $18.330 \mathrm{~mL}$ ), berarti $2,8 \mathrm{x}$ dari jumlah susu formula $(6.853 \mathrm{~mL})$. Dampak pemberian susu probiotik dan nonprobiotik terhadap peningkatan berat badan bayi dari saat lahir (BBL) sampai usia 4 minggu (BB 4 minggu) tertera pada Tabel 3. 


\section{Pembahasan}

Hasil penelitian kami menunjukkan bahwa kenaikan berat badan bayi baru lahir yang diberikan kombinasi ASI dan formula mengandung probiotik dibandingkan dengan yang mendapat susu formula nonprobiotik, bukan oleh karena jenis susu formula. Faktor yang berhubungan dengan peningkatan berat badan bayi, yaitu jenis kelamin, lama menyusui, dan susu formula pada kedua kelompok tidak berbeda secara bermakna. Dengan demikian tidak terdapat perbedaan berat badan pada penelitian kami tidak dipengaruhi oleh ketiga faktor di atas.

Pada bayi yang lahir secara seksio sesarea terjadi perubahan kolonisasi mikrobiota usus yang ditandai dengan jumlah kuman yang menguntungkan, yaitu bifidobakterium lebih rendah dibandingkan dengan C. difficile. ${ }^{14-16}$ Pertumbuhan bifidobakterium akan terhambat dan akan mencapai jumlah yang normal pada usia 6 bulan. ${ }^{17}$ Pemberian probiotik pada bayi saat lahir akan mengubah kolonisasi usus sehingga pada usia 1 bulan diharapkan tidak didominasi oleh clostridium tetapi oleh bifidobakterium. Berbagai penelitian melaporkan pemberian probiotik memiliki efek menguntungkan bagi kesehatan manusia dengan menormalkan mikrobiota usus dan imunomodulasi saluran cerna. ${ }^{16,17}$

Pada penelitian kami sejak lahir bayi telah telah mendapat susu formula mengandung probiotik, tetapi dampaknya pada usia 4 minggu tidak menunjukkan perbedaan peningkatan berat badan yang bermakna antara yang mendapat susu formula mengandung probiotik dan nonprobiotik. Hal tersebut mungkin disebabkan karena subjek penelitian kami, baik kelompok probiotik maupun nonprobiotik juga mendapat ASI dalam jumlah yang cukup banyak, yaitu pada kelompok yang nonprobiotik jumlah ASI 2,8 kali jumlah formula. Kekebalan yang didapat dari ASI merupakan salah satu faktor yang menguntungkan kondisi kesehatan bayi seperti yang terlihat pada penelitian kami, pada follow up sampai usia 4 minggu tidak didapatkan bayi yang mengalami sakit. Keadaan tersebut mungkin yang menyebabkan tidak tampaknya perbedaan peningkatan berat badan antara kedua kelompok. Dengan demikian, keterbatasan pada penelitian kami adalah susu formula yang mengandung probiotik diberikan pada ibu yang mendapat ASI dalam jumlah yang cukup sehingga pemberian susu formula mengandung probiotik tidak tampak dampaknya terhadap peningkatan berat badan antara kelompok yang mendapat susu formula mengandung probiotik dan nonprobiotik.

Kenaikan berat badan yang tidak berbeda pada penelitian kami juga dilaporkan pada penelitian yang dilakukan pada bayi sapi sehat setelah diberikan probiotik selama 6 dan 8 minggu. Pada kelompok binatang tersebut dilakukan pada binatang yang lahir tidak dengan seksio sesarea. Peneliti tersebut tidak menjelaskan mengapa tidak terjadi perbedaan peningkatan berat badan.,

Perbedaan peningkatan berat badan secara bermakna hanya tampak pada sapi dan marmot yang sedang mendapat pengobatan antibiotik dan diberikan probiotik. ${ }^{5-8}$ Begitu juga penelitian yang dilakukan pada bayi prematur yang mendapat pengobatan antibiotik serta diberikan probiotik, peningkatan berat badan lebih tinggi dibandingkan dengan kelompok kontrol. ${ }^{11,12}$ Pada penelitian terhadap binatang tidak terdapat penjelasan mengapa terdapat perbedaan, tetapi pada bayi prematur, pemberian probiotik akan mempengaruhi pola mikrobiota usus yang selanjutnya akan meningkatkan jumlah kuman bifidobakterium yang akan menyebabkan perubahan respons imun pada bayi tersebut sehingga bayi menjadi lebih sehat.

Kesimpulan penelitian ini adalah peningkatan berat badan bayi dari sejak lahir sampai usia 4 minggu yang mendapat kombinasi ASI dengan susu formula mengandung probiotik dan nonprobiotik tidak berbeda. Perlu penelitian lebih lanjut untuk menentukan pengaruh probiotik terhadap peningkatan berat badan bayi baru lahir pada bayi yang tidak mendapat ASI dalam jumlah yang cukup.

\section{Daftar pustaka}

1. Cornellan J, Cohen SB, Wheelwright S, Batki A, Ahluwalia J. Sex differences in human neonatal social perception. Infant Behavior Develop 2001;23:113-8.

2. Borys P. Model of the newborn"s physical development. Acta Physica Polonica B 2010;41:1105-10.

3. Morril JL, Morril JM, Feyerhierm JF. Plasma proteins and a probiotic as ingridients in milk replacer. J Dairy Sci 1999;78;920-7.

4. Kamra DN, Chaudary LC, Neeta A, Singh R, Pathak NN. Growth performance, nutrient utilization, rument fermentation and enzym activities in calves fed and sacharomyces supplemned diets. Indian J Anim Sci 
2002;72:472-5.

5. Abbe F, Ishibashi N, Shimamura S. Effect of administration of bifidobacteria and lactic acid bacteria to newborn calves and piglets. J Dairy Sci 1995;78:2838-46.

6. Gorgullu M, Siuta A, Yustervsen E, Kathlu AR. Effect of probiotics on growing performance and health calves. Cuban J Agric Sci 2003;37:125-9.

7. Balevi T, Ucan US, Cokun B, Kurtolu V, Cetingul IS. Effect of dsietary probiotic on performance and humoral immune response in layer hen. Br Poult Sci 2001;42:456-61.

8. Donovan DC, Franklin ST, Chase CCL, Hippen AR. Growth and health of holstein calves feds milk replacers supplemented with antibiotics or enteroguard. J Dairy Sci 2002;85:947-50.

9. Aldana C, Cabra S, Ospina CA, Carjaval F, Rodriguez F. Effect of a probiotic compound in rumen development, diarrhea incidence and weight gain in young holstein calves. World Academy of Science, Engineering and Technology 2009;57:378-81.

10. Hossaini SMR, Bojarpur M, Marnouei M, Assadian A, Fayazi J. Effect of probiotics supplementation in daily milk intake of newborn calves on feed intake body weight gain, fecal scores and health condition. J Animal Vetenary Advances 2010;5:872-5.

11. Mohan R, Koebnick C, Schiltdt Z, Mueller M, Radke M, Blaut M. Effect of Bifidobacterium lactis Bb 12 supplementation on body weight, fecal $\mathrm{pH}$, acetat, lactate, calprotectin, and IgA in preterm infants. Pediatr Res 2008;64:418-22.

12. Kitajima H, Sumida Y, Tanaka R. Early administration of Bifidobacterium Breve to Preterm Infant: randomized controlled trial. Arch Dis Child Fetal Neonatal 1997;76:192-6.

13. Haschke F, Wang W, Ping G, Varawitiya A, Podhipak A, Rochat F, dkk. Clinical trials prove the safety and efficacy of the probiotic strain Bifidobacterium $\mathrm{Bb} 12$ in follow-up formula and growing-up milks. Monatshr Kinderheld. 1998;146 Suppl:1426-30.

14. Kiani L. Bugs in our guts - not all bacteria are bad: how probiotics keep us healthy. CSA Discovery Guides 2006;20:42-9.

15. Penders J, Thijs C, Vink C. Factors influencing the composition of the intestinal microbiota in early infancy. Pediatrics 2006;118:511-21.

16. Langhendries J, Detri J, Van Heess J, Lambory J, Darimon J, Mozain M, dkk. Effect of a fermented infant formula containing viable bifidobacteria on the fecal flora composition and $\mathrm{pH}$ of healthy full-term infants. J Pediatr Gastroenterol Nutr 1995;21:177-81.

17. Gronlund M, Lehtonen O, Eerola E, Kero P. Fecal microflora in healthy infants born by different methods of delivery:permanent changes in intestinal flora after cesarean delivery. J Pediatr Gastroenterol Nutr 1999;28:34-9. 